\title{
Using a benthic lander to explore and monitor vulnerable ecosystems in the Mediterranean Sea
}

\author{
Gianfranco D’Onghia, Francesca Capezzuto, Roberto Carlucci, Angela Carluccio, Porzia Maiorano, \\ Michele Panza, Pasquale Ricci, Letizia Sion, Angelo Tursi
}

Department of Biology, University of Bari Aldo Moro, Via E. Orabona 4, 70125 Bari-CoNISMa Local Research Unit

\begin{abstract}
The MEMO (Marine Environment MOnitoring system) baited lander is used to explore and monitor marine ecosystems in the Mediterranean Sea. MEMO is equipped with 2 video cameras, a multiparametric probe and a current meter, fully operative down to $1000 \mathrm{~m}$ in depth for 24 consecutive hours. Since 2010, the ecology team of the Department of Biology of the University of Bari (Italy) deployed the MEMO lander in some sensitive and vulnerable deep-sea habitats of the Mediterranean Sea, as part of national and international research projects. Data on environmental parameters (depth, salinity, temperature and current) and related to benthopelagic species, their small-scale distribution, size and behaviour, have been recorded. MEMO has been also deployed in fragile and structurally complex habitats, such as coralligenous and cold-water coral habitats, in order to monitor physico-chemical and biological variables as part of the EU Marine Strategy Framework Directive. Some main applications of the MEMO lander are reported here, with indications of relative advantages and limitations.
\end{abstract}

\section{Section: RESEARCH PAPER}

Keywords: Journal; template; IMEKO; Microsoft Word

Citation: Gianfranco D’Onghia, Francesca Capezzuto, Roberto Carlucci, Angela Carluccio, Porzia Maiorano, Michele Panza, Pasquale Ricci, Letizia Sion, Angelo Tursi, Using a benthic lander to explore and monitor vulnerable ecosystems in the Mediterranean Sea, Acta IMEKO, vol. 7, no. 2, article 8, June 2018, identifier: IMEKO-ACTA-07 (2018)-02-08

Section Editor: Fabio Leccese, Università degli Studi di Roma Tre, Italy

Received January 18, 2018; In final form March 23, 2018; Published June 2018

Copyright: (C) 2018 IMEKO. This is an open-access article distributed under the terms of the Creative Commons Attribution 3.0 License, which permits unrestricted use, distribution, and reproduction in any medium, provided the original author and source are credited

Corresponding author: Gianfranco D’Onghia, e-mail: gianfranco.donghia@uniba.it

\section{INTRODUCTION}

Several systems exist to take photographs and videos of organisms and habitats in deep waters, ranging from submersible to Remotely Operated Vehicle (ROV), from landers to underwater platforms settled on the bottom [1]-[6]. In addition to foto- or video- cameras, all these systems can be equipped with CTD, current meters, sediment traps, baitrelease and other devices. Although all these systems suffer from the fact that quantification and even identification of species can be doubtful, their low impact has become fundamental in the study of sensitive and vulnerable habitats, where grabs, sledges and fishing gears would damage the benthic fauna and habitats unacceptably [4], [5], [7], [8]. Moreover, video systems are innovatory since they allow to collect data on environmental parameters, seafloor features, habitat and associated fauna, even in less accessible habitats, such as seamounts and canyons [7]-[10].

The main applications of a baited lander used to explore and monitor marine ecosystems in the Mediterranean Sea, with indications of advantages and limitations, are reported in this paper.

\section{LANDER TECHNICAL FEATURES}

The ecology team of the Department of Biology has developed the MEMO (Marine Environment MOnitoring system) baited lander, as part of the EU_7FP CoralFISH project, with the aim of investigating the seafloor characteristics, biological diversity and environmental variables in the deep-sea ecosystems. The MEMO lander consists of a stainless steel frame (ø $2.15 \mathrm{~m}$; h $1.65 \mathrm{~m}$ ); 2 video cameras (HD Multi SeaCam) with 2 white LED lights, an electronic compass, inclinometer and altimeter; a multiparametric probe (Sea-Bird Electronics Seacat Profiler 19 plus) for the measurement of pressure, temperature, conductivity, oxygen, $\mathrm{pH}$ and turbidity; a Doppler current meter (Nortek Aquadopp 2000); 4 Deep-Sea batteries (12 V, $80 \mathrm{Ah}$ ); an acoustic modem (Teledyne Benthos ATM-900 Series); an electronic control unit (Communication 
Technology, Ltd) capable of managing the entire system (Figure 1). On the seabed MEMO is linked by a zinc-coated steel cable to buoys which keep the cable under tension (back up buoys) and then to a surface floating signalling buoy. The system is lowered to the seabed by winch and the surface buoy remains connected for recovery. Continuous connection is maintained via the acoustic modem with an on board PC software platform, making images and sensor data available on the vessel. The MEMO lander can work down to $1000 \mathrm{~m}$ in depth for 24 consecutive hours and can be baited. By means of an ad hoc methodological approach of image analysis, the videos recorded by both video-cameras during each deployment are analysed using the Adobe Premier Pro software and information on abundance and behaviour of bentho-pelagic species, including those of fishery interest, is collected. Moreover, sizes of recorded specimen are measured from images using Image J 1.46q, a Java-based public domain program.

\section{MAIN APPLICATIONS}

The MEMO lander has been mostly deployed in some sensitive and vulnerable deep-sea habitats of the Mediterranean Sea, such as the Santa Maria di Leuca (SML) cold-water coral (CWC) province (Northern Ionian Sea) and the Bari Canyon (BC) (Southern Adriatic Sea), as part of national and international research [9]-[16] (Table 1). Data on the characteristics of substrate together with depth $(\mathrm{m})$, salinity (psu), temperature $\left({ }^{\circ} \mathrm{C}\right)$ and current $(\mathrm{m} / \mathrm{s})$ were recorded. Data on the species composition and abundance as well as their small scale-distribution and behaviour were also recorded. In order to estimate the species abundance, both the time of first arrival (1 $1^{\text {st }}$ arrival time), i.e. the time after touchdown in which a given species first arrives, and the maximum number of individuals in a single frame $(\operatorname{Max} N)$ were also recorded by species [17].

A contribution to the knowledge of the deep-sea megafauna diversity in the SML CWC province and $\mathrm{BC}$ was provided in [9], [11]-[16]. The first in situ documentation of the crab Paromola cuvieri behaviour interacting with other deep-sea

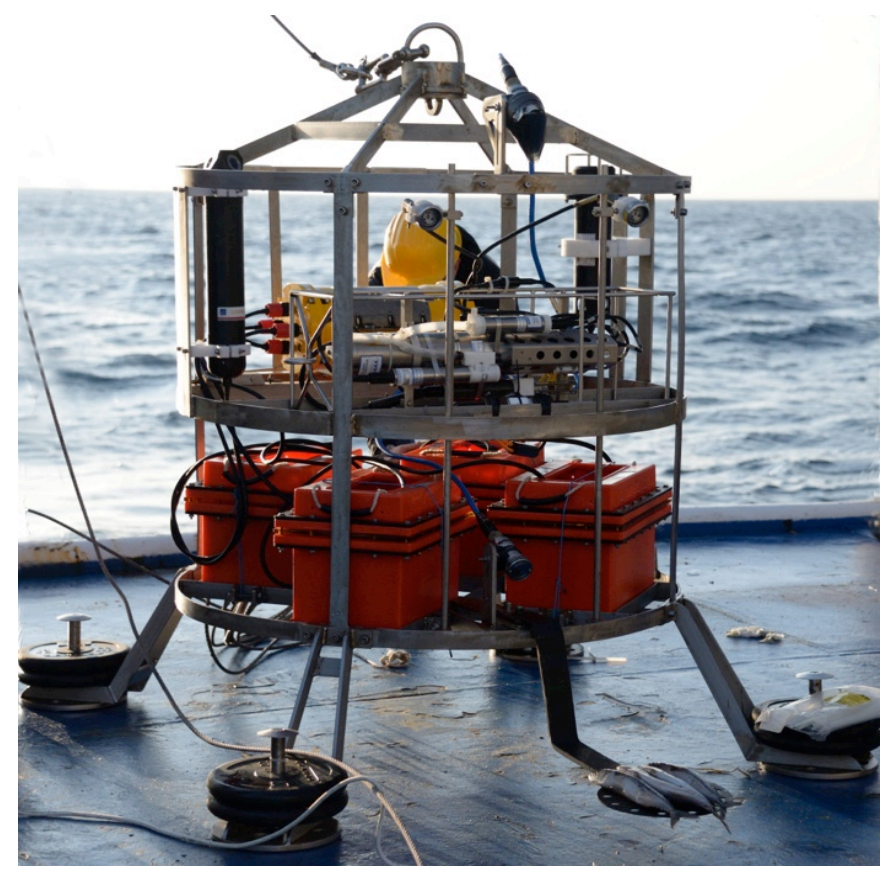

Figure 1. The MEMO lander equipment. species in the Mediterranean Sea was reported [11]. This crab was recorded at depths between 547 and $648 \mathrm{~m}$ in the SML CWC province. All the specimens carried a sponge on their exoskeleton using the pereiopods. They were distinguishable by the size and shape of the carried sponge. Both passive covering behaviour and active behaviour were observed. In fact, some specimens of $P$. cuvier $i$ were observed to use the sponge to push away oncoming possible competitors, such as the teleost fish blackbelly rosefish (Helicolenus dactylopterus), or to discourage the attacks of other scavengers and/or predators, such as the bluntnose sixgill shark (Hexanchus griseus) [11] (Figure 2).

While investigating the benthopelagic fauna of the SML CWC province, a total of 20 benthopelagic species (1 cephalopod, 6 decapod crustaceans, 5 chondrichthyes and 8 osteichthyes) were identified at depths between 547 and $790 \mathrm{~m}$ [12]. The fish blackspot seabream (Pagellus bogaraveo) was exclusively observed in the coral habitat. The fishes European conger (Conger conger) (Figure 3) and $H$. dactylopterus were the most abundant species in this type of habitat [12]. A positive significant relationship between the species abundance and the current speed was detected in the investigated habitats [16].

The occurrence and behaviour of the sharks - the gulper (Centrophorus granulosus), the kitefin (Dalatias licha), the velvet belly (Etmopterus spinax) and the bluntnose sixgill (Hexanchus griseus) - in the SML CWC province were also recorded [13].

During four deployments of MEMO carried out in the BC, at depths of 443-788 m, a total of 12 benthopelagic fish species were identified [9], [14]. The blackspot seabream was the most observed fish species. Groups of up to 40 individuals of $P$. bogaraveo were attracted to the bait and were observed even in single frames. In particular, individuals were both exploring the

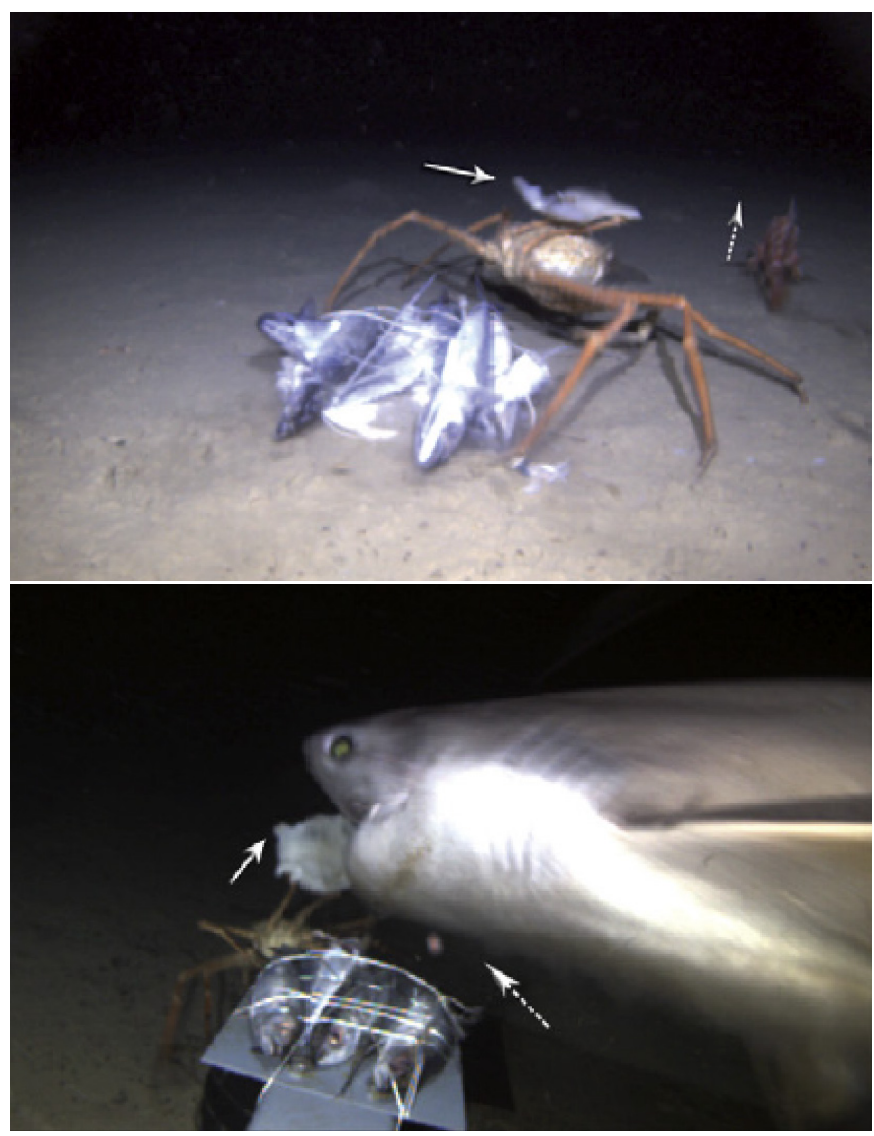

Figure 2. Digital frames showing the active behaviour of Paromola cuvier and its interaction with Helicolenus dactylopterus (above) and Hexanchus griseus (below) recorded by MEMO lander in the SML CWC province. 


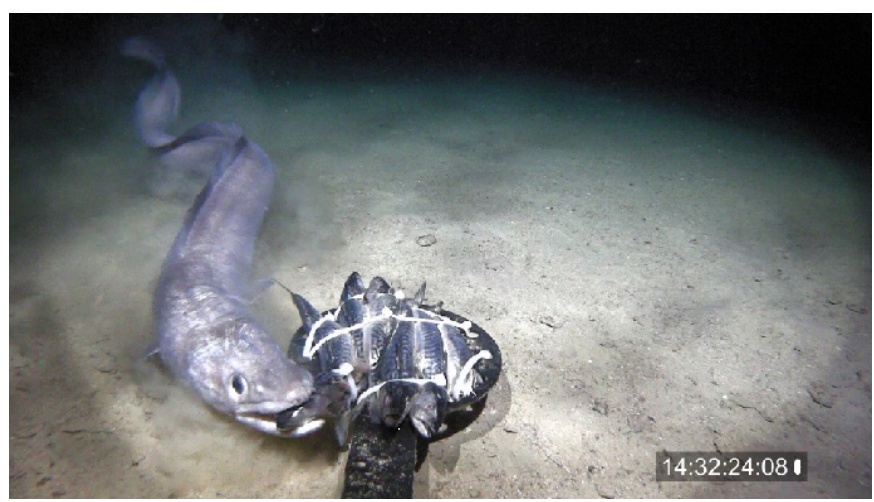

Figure 3. Digital frame of Conger conger recorded by MEMO lander in the SML CWC province.

area and feeding actively on the bait (Figure 4). A gregarious behaviour was observed. Detection of $P$. bogaraveo individuals increased significantly when the current velocity decreased.

The European conger was recorded at each deployment. Clear scavenger behaviour was also observed in this teleost fish and in the shark E. spinax. The shark species C. granulosus and $H$. griseus were also recorded but, although attracted by the bait, they were never seen feeding on it. Other fish species, harvested on fishing grounds, such as Merluccius merluccius, $H$. dactylopterus and Polyprion americanus (Figure 5), were also recorded in $\mathrm{BC}$.

Since 2015, the MEMO lander has also been used as part of the monitoring activity foreseen by the EU Marine Strategy

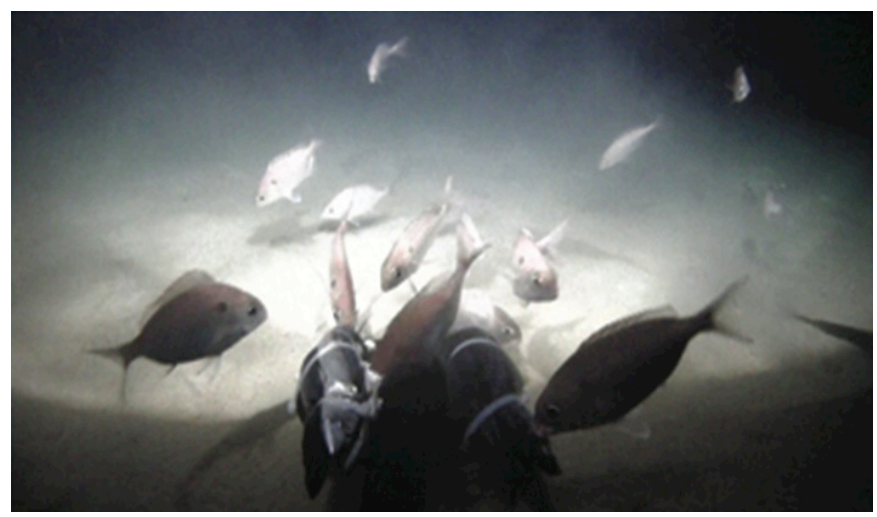

Figure 4. Digital frame of Pagellus bogaraveo recorded by MEMO lander in the Bari Canyon.

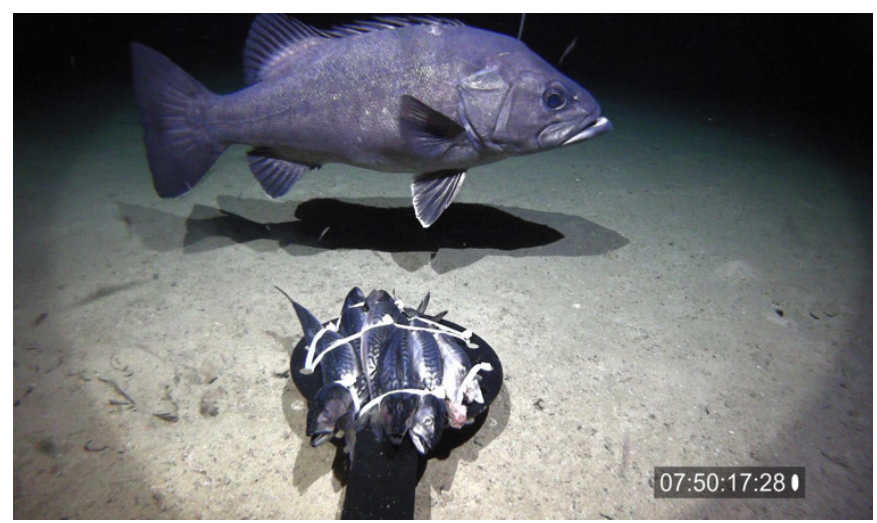

Figure 5. Digital frame of Polyprion americanus recorded by MEMO lander in the Bari Canyon.
Framework Directive (MSFD) to detect changes in the sensitive and vulnerable habitats, not only in CWC sites and canyons but also in coralligenous and maerl habitats. For example, during 2016 MEMO was deployed off Vieste and off Pontine islands to observe coralligenous and maerl habitats, respectively. During two deployments in coralligenous habitats, environmental parameters were recorded and a total of 10 species (2 decapod crustaceans and 8 teleost fishes) were identified (Figure 6). In maerl habitat off Pontine islands a total of 6 taxa (2 crustaceans, 1 echinoderm and 3 teleost fishes) were identified (Figure 7) (Ta ble 1).

\section{ADVANTAGES AND LIMITATIONS}

A benthic lander like MEMO, equipped with video cameras together with CTD, current meters and other devices have a great potential in monitoring changes in the ecosystems [5], [17]-[19]. It is highly suitable for recording physico-chemical parameters on the bottom, observing local bottom features and counting fish and invertebrates, providing a new insight on species small-scale distribution, behaviour and interactions. A benthic lander can be deployed in structurally complex habitats, such as CWC communities, canyons and seamounts. It is relatively non-destructive and less invasive, thus reducing the impact of the investigation on sensitive and fragile habitats. In general, a benthic lander needs a small sea time requirement for a long observation. Its deployment and recovery is also possible from smaller vessels [5], [9], [16], [18], [20].

However, several difficulties and limitations should be taken into consideration during analysis of mobile benthopelagic fauna [5], [18]. One of the key difficulties in dealing with deep waters is low faunal density, which requires a very large sampling effort in order to have valid estimates. Low densities
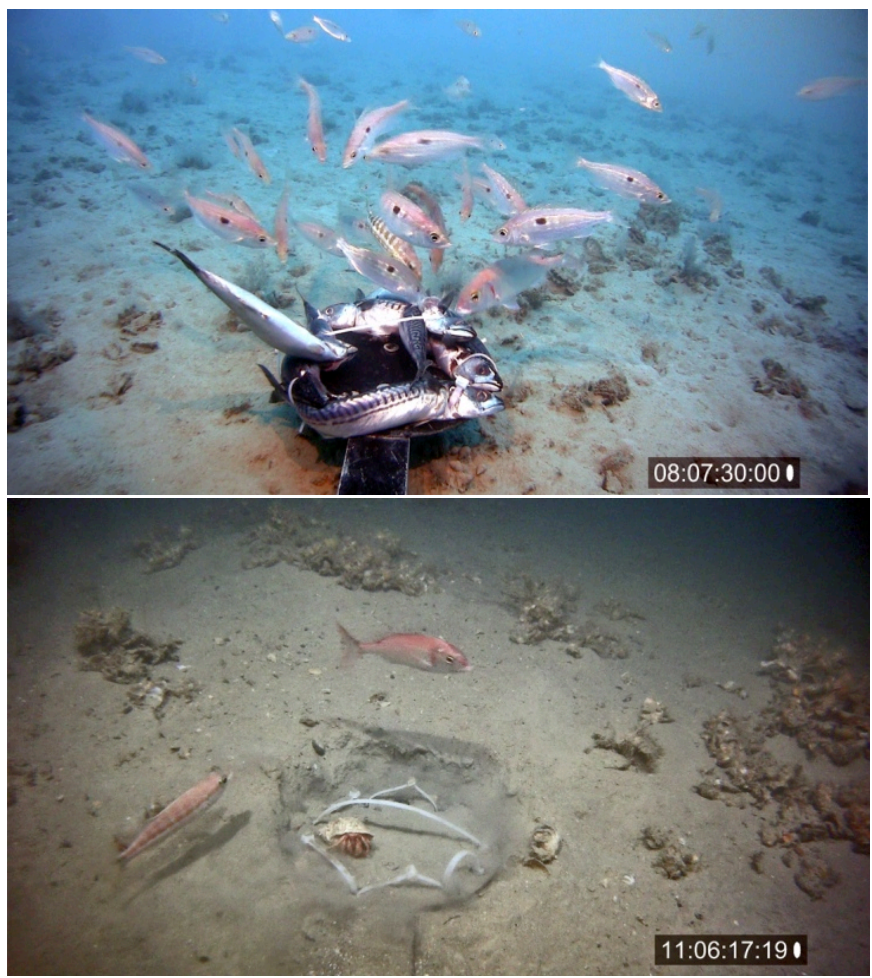

Figure 6. Digital frames of Pagellus erythrinus, Serranus cabrilla, Spicara flexuosa, (above) and Dardanus arrosor, Pagellus erythrinus, Serranus cabrilla (below) recorded by MEMO lander in coralligenous habitat off Vieste. 
Table 1. List of habitats explored by means of the MEMO lander in different surveys, years and areas with indication of the investigated depth range and total number $(\mathrm{N})$ of the bentho-pelagic species video recorded.

\begin{tabular}{|c|c|c|c|c|c|}
\hline Survey & Year & Area & Habitat & Depth (m) & $\mathrm{N}$ of species \\
\hline CoralFISH, OBAMA, MSFD & $2010,2011,2015$ & SML, Tricase & coral & $547-797$ & 24 \\
\hline RITMARE, MSFD & 2012, 2015, 2016 & Bari and Nora Canyons & canyon & $442-788$ & 27 \\
\hline CoralFISH, OBAMA, MSFD & $2010,2011,2015$ & SML, Gallipoli, Monopoli & mud & $485-790$ & 20 \\
\hline MSFD & 2015,2016 & Vieste, Egadi Islands & coralligenous & $55-96$ & 16 \\
\hline MSFD & 2016 & Pontine Islands, Egadi Islands & maerl/rhodoliths & $63-87$ & 7 \\
\hline
\end{tabular}

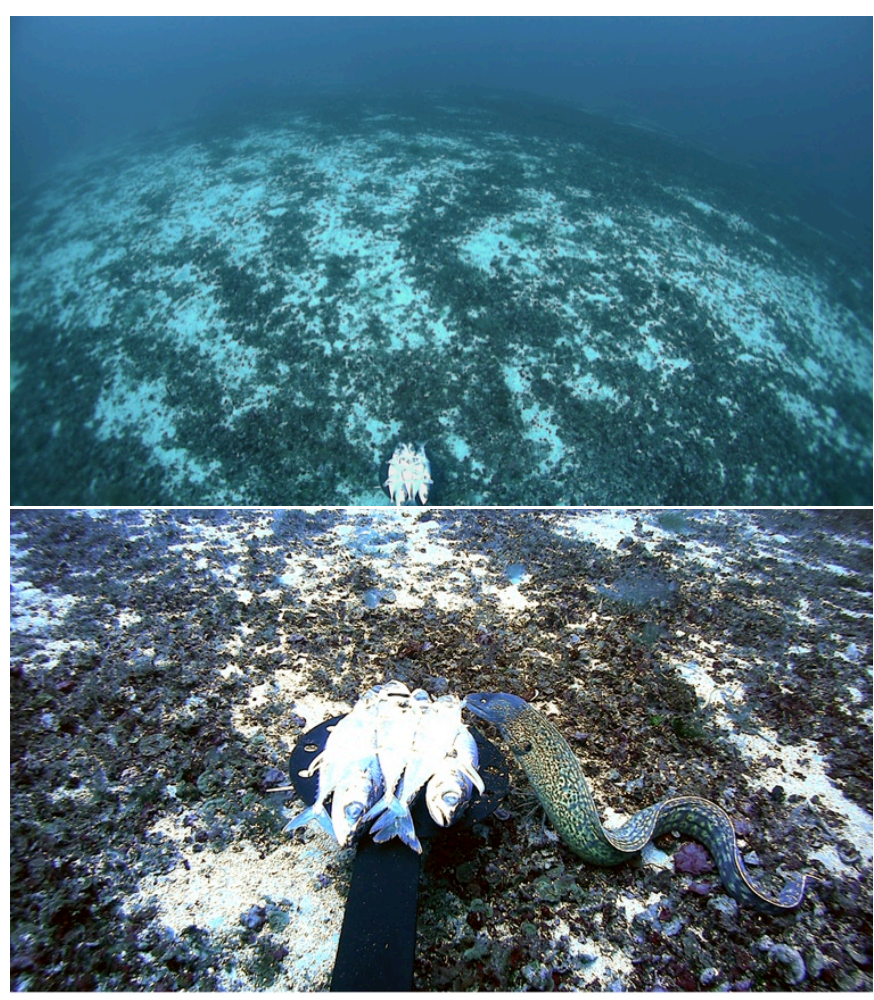

Figure 7. Digital frames of maerl habitat as seen by the upper camera (above) and Muraena helena feeding on bait (below) recorded by MEMO lander off Pontine islands.

make statistical comparison between areas difficult because of the high variance in replicate counts. In addition, identifying invertebrates and fishes to species level only from video can also be challenging in areas with a high species diversity. Although landers produce little disturbance when collecting data, they will only attract scavenging invertebrates and fishes, so are highly selective. Precise positioning of the lander can also prove difficult. Due to the complex topography of the CWC and canyon habitats, free fallings landers may sometimes miss their target or land directly on the corals causing damage and increasing the risk of entanglement. Other disadvantages consist of equipment cost and relatively chance of its loss, many assumptions in the abundance estimates as well as in the weight of the animals, which cannot be determined directly, requiring the adoption of the length-weight relationships [20].

\section{CONCLUSIONS}

The applications of the MEMO lander reported in this paper represent in situ documentation, with a very low impact, of the environmental parameters and fauna in sensitive and vulnerable habitats. They have provided new insights into megafauna diversity in the SML CWC province and BC, small scale distribution and behaviour of invertebrates and fishes and linkage between species and habitats. Since these habitats show a high biodiversity and can act as refuge sites for valuable species [4], [14], they often are impacted by fishing activities and other anthropogenic injuries [8].

In addition to the use of a benthic lander, a ROV can be a good complementary tool with the lander to investigate deepsea habitats since it explores a larger area, recording the sessile fauna (corals, sponges) distributed on the seafloor. However, the ROV has limitations mainly related to noise and light created by the gear typology that may either scare away or attract invertebrates and fishes causing under or over estimations of their true abundances [3], [4], [6], [21].

\section{ACKNOWLEDGEMENTS}

This paper benefited from data recorded during the EU_7FP CoralFISH project, OBAMA_PRIN and RITMARE projects funded by the Italian Ministry of University and Research (MIUR), Marine Strategy Framework Directive monitoring project funded by the Italian Ministry of the Environment (MATTM). The authors wish to thank Daniela Potenza for setting up the figures and the table.

\section{REFERENCES}

[1] I.G. Priede, P.M. Bagley, J.D. Armstrong, K.L. Smith, N.R. Merrett, "Direct measurement of active dispersal of food-falls by deep-sea demersal fishes", Nature, Vol. 351, 1991, pp. 647-649.

[2] P.B. Adams, J.L. Butler, T.E. Laiding, K.A. Dahlin, W.W. Wakefield, "Population estimates of Pacific coast groundfishes from video transects and swept-area trawls", Fishery Bulletin, Vol. 93, 1995, pp. 446-455.

[3] V.M. Trenkel, P. Lorance, S. Mahevas, "Do visual transects provide true population density estimates for deepwater fish?", Ices Journal of Marine Science, Vol. 61(7), 2004, pp. 1050-1056.

[4] M.J. Costello, M. McCrea, A. Freiwald, T. Lundälv, L. Jonsson, B.J. Bett, T.C.E. van Weering, H. de Haas, J.M. Roberts, D. Allen, "Role of cold-water Lophelia pertusa coral reefs as fish habitat in the NE Atlantic", In: Freiwald A., Roberts J.M. (eds), Cold-Water Corals and Ecosystems. Springer-Verlag Berlin Heildelberg, 2005, pp. 771-805.

[5] D.M. Bailey, N.J. King, I.G. Priede, "Cameras and carcasses: historical and current methods for using artificial food falls to study deep-water animals", Mar. Ecol. Prog. Ser., Vol. 350, 2007, pp. 175-178.

[6] A.W. Stoner, C.H. Ryer, S.J. Parker, P.J. Auster, W.W. Wakefield, "Evaluating the role of fish behavior in surveys conducted with underwater vehicles", Can. J. Fish Aquat. Sci., Vol. 65, 2008, pp. 1230-1243.

[7] F.M. Porteiro, J.N. Gomes-Pereira, C.K. Pham, F. Tempera, R.S. Santos, "Distribution and habitat association of benthic fish on the Condor seamount (NE Atlantic, Azores) from in situ observations", Deep-Sea Res Part II, Vol. 98, 2013, pp. 114-128.

[8] A. Cau, A. Alvito, D. Moccia, S. Canese, A. Pusceddu, R. Cannas, M. Angiolillo, M.C. Follesa, "Submarine canyons along the upper Sardinian slope (Central Western Mediterranean) as 
repositories for derelict fishing gears", Marine Pollution Bulletin, Vol. 123, (1-2), 2017, pp. 357-364.

[9] G. D’Onghia, F. Capezzuto, A. Carluccio, R. Carlucci, A. Giove, F. Mastrototaro, M. Panza, L. Sion, A. Tursi, P. Maiorano, "Exploring composition and behaviour of fish fauna by in situ observations in the Bari Canyon (Southern Adriatic Sea, Central Mediterranean)", Marine Ecology, Vol. 36, 2015, pp. 541-556.

[10] A. Cau, M.C. Follesa, D. Moccia, A. Bellodi, A. Mulas, M. Bo, S. Canese, M. Angiolillo, R. Cannas, "Leiopathes glaberrima millennial forest from SW Sardinia as nursery ground for the small spotted catshark Scyliorbinus canicula", Aquatic Conservation: Marine and Freshwater Ecosystems, Vol. 27, (3), 2017, pp. 731-735.

[11] F. Capezzuto, P. Maiorano, M. Panza, A. Indennidate, L. Sion, G. D'Onghia, "Occurrence and behaviour of Paromola cuvieri (Crustacea, Decapoda) in the Santa Maria di Leuca cold-water coral community (Mediterranean Sea)", Deep-Sea Research I, Vol. 59, 2012, pp. 1-7.

[12] P. Maiorano, L. Sion, F. Capezzuto, R. Carlucci, F. Mastrototaro, M. Panza, A. Tursi, G. D’Onghia, “Exploring deep-sea benthopelagic fauna using a baited lander in the Santa Maria di Leuca cold-water coral province", Rapp. Comm. int. Mer Médit., Vol. 40, 2013, pp. 719.

[13] L. Sion, F. Capezzuto, R. Carlucci, A. Carluccio, A. Indennidate, P. Maiorano, G. D'Onghia, "Behaviour of deep-sea sharks observed in the Santa Maria di Leuca cold-water coral province", Rapp. Comm. int. Mer Médit., Vol. 40, 2013, pp. 494.

[14] G. D'Onghia, F. Capezzuto, F. Cardone, R. Carlucci, A Carluccio, G. Chimienti, G. Corriero, C. Longo, P. Maiorano, F. Mastrototaro, P. Panetta, A. Rosso, R. Sanfilippo, L. Sion, A. Tursi, "Macro- and megafauna recorded in the submarine Bari Canyon (southern Adriatic Sea, Mediterranean Sea) using different tools", Mediterranean Marine Science, Vol. 16, No.1, 2015b, pp. 180-196.
[15] T.D. Linley, M. Lavaleye, P. Maiorano, M. Bergman, F. Capezzuto, N. Cousins, G. D’Onghia, G. Duineveld, M. Shields, L. Sion, A. Tursi, I.G. Priede, "Interaction of cold-water corals with fish diversity and density across differing European regions: data from three baited lander systems", Deep Sea Res. II., Vol. 145, 2017, pp. 8-21.

[16] P. Maiorano, F. Capezzuto, C. Calculli, R. Carlucci, A. Carluccio, L. Cornacchia, M. Panza, A. Pollice, L. Sion, A. Tursi, G. D'Onghia, "In situ observations of the benthopelagic fauna in the Santa Maria di Leuca Cold-Water Coral province (Central Mediterranean)", PLOS ONE, submitted.

[17] N.J. King, I.G. Priede, "Coryphaenoides armatus, the Byssal Grenadier: Global Distribution, Abundance, and Ecology ad Determined by Baited Cameras", Am. Fish. Soc. Symp., Vol. 63, 2008, pp. 139-161.

[18] G. D’Onghia, J.H. Fosså, "Regional comparisons of different fish assemblages recorded from analysis of in situ video", EUProject CoralFISH, Deliverable D50-Report, 2012, pp. 166.

[19] J.M. Roberts, O.C. Peppe, L.A. Dodds, D.J. Mercer, W.T. Thomson, J.D. Gage, D.T. Meldrum, "Monitoring environmental variability around cold-water coral reefs: the use of a benthic photolander and the potential of seafloor observatories", In: Freiwald A., Roberts J.M. (eds), Cold-Water Corals and Ecosystems. Springer-Verlag Berlin Heildelberg, 2005, pp. 483-502.

[20] A.J. Jamieson, D.M. Bailey, H.J. Wagner, P.M. Bagley, I.G. Priede, "Behavioural responses to structures on the seafloor by the deep-sea fish Coryphaenoides armatus: Implications for the use of baited landers", Deep-Sea Res. I, Vol. 53, 2006, pp. 11571166.

[21] C.H. Ryer, A.W. Stoner, P.J. Iseri, M.L. Spencer, "Effects of simulated underwater vehicle lighting on fish behavior", Mar. Ecol. Prog. Ser., Vol. 391, 2009, pp. 97-10. 